\title{
EKSPANSJA CHIŃSKIEGO KAPITALU W EUROPIE - POTENCJALNE SZANSE I ZAGROŻENIA DLA POLSKI
}

Dynamiczny rozwój gospodarczy Chińskiej Republiki Ludowej jest jednym z najistotniejszych czynników, kształtujących międzynarodowe stosunki gospodarcze i polityczne na początku XXI wieku. Wzrost potęgi gospodarczej państwa chińskiego, objawia się na wielu płaszczyznach, a jedną z nich jest rosnąca aktywność inwestycyjna na rynkach międzynarodowych przedsiębiorstw z ChRL realizujących strategię go global. Pewnym novum, obserwowanym w ostatnich latach jest ekspansja chińskiego kapitału na rynki państw rozwiniętych. Zjawisko to, szeroko komentowane w środowiskach politycznych i naukowych, budzi pewne kontrowersje. Wskazuje się zarówno potencjalne korzyści ekonomiczne, które mogą mu towarzyszyć, jak i sytuowane na „styku” polityki i gospodarki zagrożenia z nim związane.

Celem niniejszego artykułu jest analiza zjawiska ekspansji chińskiego kapitału w Europie, przy uwzględnieniu jego charakteru, skali, przesłanek, a także możliwych konsekwencji. Zamiarem jest prezentacja przebiegu dyskursu politycznego i naukowego, toczącego się wokół szans i zagrożeń, jakie niesie ze sobą wzrost zaangażowania inwestycyjnego podmiotów z ChRL w Europie.

\section{WZROST ZAANGAŻOWANIA INWESTYCYJNEGO CHIŃSKICH FIRM W EUROPIE}

W ostatnich latach zaobserwować można znaczny wzrost aktywności chińskiego kapitału w Europie, na co wpływ mają problemy ekonomiczne państw europejskich i relatywnie silna kondycja gospodarki Chińskiej Republiki Ludowej. Stopniowej redefinicji ulega dotychczasowy model współpracy ekonomicznej między państwami Unii Europejskiej a ChRL. Chiny, dotychczas zainteresowane przede wszystkim absorpcją kapitału i napływem bezpośrednich inwestycji zagranicznych, a także eksportem własnych towarów na rynki europejskie, coraz częściej stają sięźródłem kapitału inwestycyjnego w państwach Europy (Hanemann, 2012), a także Afryki, Ameryki Łacińskiej oraz w Stanach Zjednoczonych. Zmianie ulega także sposób oceny chińskiego zaangażowania inwestycyjnego przez europejskich decydentów. Dotychczas w dużej mierze sceptyczni i nieufni, coraz częściej postrzegają chińskie inwestycje jako remedium na problemy pogrążonych w kryzysie zadłużeniowym państw. Za główne czynniki, mające wpływ na zmiany w relacjach między Europą a ChRL należy uznać:

1) problemy gospodarcze państw europejskich - dla wielu z nich chińskie inwestycje oznaczają napływ bardzo potrzebnego dla pobudzenia gospodarki kapitału. Przy- 
czyniają się do tworzenia nowych (w przypadku inwestycji typu greenfield), bądź utrzymania istniejących miejsc pracy (w przypadku akwizycji i dokapitalizowania zmagających się z problemami firm). Część państw liczy ponadto na chińskie zaangażowanie w wykup emitowanych przez nie obligacji. Dotyczy to w szczególności państw zmagających się z kryzysem zadłużeniowym ${ }^{1}$. Perturbacje ekonomiczne doprowadziły także do ,przeceny” części wartościowych aktywów w Europie, co stanowi zachętę dla coraz aktywniejszych globalnie firm z ChRL. Należy podkreślić, że o chiński kapitał zabiegają nie tylko rządy, ale także europejskie przedsiębiorstwa, które starają się zabezpieczyć w ten sposób swoją przyszłość (Godement, Parello-Plesner, 2011: 8; Streaks of red, 2012);

2) ogromne rezerwy walutowe ChRL i poszukiwanie przez to państwo alternatywnych sposobów ich inwestowania. Thilo Hanemann i Daniel H. Rosen - autorzy raportu amerykańskiej firmy konsultingowej Rhodium Group pt. China Invests in Europe. Patterns, Impacts and Policy Implications podkreślają, że dla posiadającej nadwyżkę rezerw walutowych ChRL koniecznościąjest poszukiwanie alternatywnych sposobów ich alokacji (Hanemann, Rosen, 2012: 25-27);

3) dążność do uzyskania technologii, know-how, przejęcia znanych marek, a także lepszego poznania przez internacjonalizujące się chińskie firmy rynków państw rozwiniętych, co ma przyczynić się do wzmocnienia ich pozycji konkurencyjnej (ibidem: 50-51).

ChRL stara się wykorzystać globalne perturbacje gospodarcze, by zdobyć możliwość większych inwestycji w Europie. Kapitał chiński trafia do Europy na trzy sposoby. Pierwszym jest wykup obligacji państw europejskich, w tym przede wszystkim państw zmagających się z poważnymi problemami gospodarczymi, takich jak Grecja czy Hiszpania (Godement, Parello-Plesner 2011: 15-16). Trudno oszacować jak bardzo Chińczycy zaangażowani są w wykup europejskiego długu. Szacuje się, że około $25 \%$ chińskich (wartych ponad 3,24 biliona USD) ${ }^{2}$ rezerw walutowych przechowywanych jest w euro. Stanowić ma to naturalną alternatywę dla dolara i element polityki dywersyfikacji posiadanych rezerw walutowych (Streaks of red, 2012). Drugim są bezpośrednie inwestycje zagraniczne - które obejmują zarówno projekty typu greenfield, fuzje, przejęcia, a także wykup mniejszościowych pakietów akcji europejskich koncernów. Na tej płaszczyźnie wzrost zaangażowania kapitałowego chińskich podmiotów w Europie jest najbardziej widoczny (Godement, Parello-Plesner, 2011: 18-22). Tej problematyce poświęcono także w niniejszym artykule najwięcej uwagi. Sposobem trzecim jest udział w przetargach publicznych na projekty infrastrukturalne. Chińskie firmy, które dotychczas angażowały się w realizację projektów infrastrukturalnych przede wszystkim w państwach Azji i Afryki, próbują wykorzystać nabyte doświadczenie w Europie, oferując przy tym bardzo konkurencyjne ceny. Należy podkreślić, że chińskie przedsiębiorstwa posiadają niewielkie doświadczenie na rynkach europej-

1 Można zakładać, że po ogłoszeniu przez Europejski Bank Centralny zamiarów skupu obligacji zadłużonych państw europejskich ten obszar zaangażowania chińskiego kapitału stracił na znaczeniu. Patrz: EBC będzie skupowat obligacje, http://www.bankier.pl (02.11.2012).

${ }^{2}$ Dane z czerwca 2012 r. za oficjalną stroną chińskiej Państwowej Administracji ds. Rezerw Walutowych (ang. State Administration of Foreign Exchange), http://www.safe.gov.cn/ (30.10.2012). 
skich, mają przy tym poważne problemy między innymi ze zrozumieniem zasad przetargów i prawa pracy. Dobrym tego przykładem jest porażka inwestycji chińskiego COVEC (ang. China Overseas Engineering Group), które według zawartej umowy miało wybudować dwa odcinki autostrady A2 między Łodzią a Warszawą (ibidem: 23-26; Gradziuk, Szczudlik-Tatar 2012: 12-15).

Wywołującym największe dyskusje problemem pozostają bezpośrednie inwestycje zagraniczne chińskich firm w Europie. Według obliczeń PricewaterhouseCoopers w 2010 r. doszło do 25 większych transakcji przejęcia przez firmy chińskie przedsiębiorstw europejskich, w 2011 r. zanotowano natomiast 44 takie przypadki. By wymienić najważniejsze z nich: firma Cosco wydzierżawiła na 35 lat port w Pireusie (zostanie on zmodernizowany), koncern Geely przejął od amerykańskiego Forda znaną szwedzką markę Volvo, Three Gorges przejęło 21\% udziałów portugalskiego przedsiębiorstwa energetycznego EDP, China Investment Corporation nabyło 8,7\% udziałów w brytyjskim Thames Water i 30\% udziałów w dwóch spółkach francuskiej energetycznej grupy GDF Suez, ChemChina wykupiło norweską spółkę Elkom (producenta polisilikonu wykorzystywanego przy produkcji ogniw słonecznych), a Sany Group po długich negocjacjach przejęło niemiecką firmę Putzmeister - producenta sprzętu budowlanego (90\% udziałów). Zauważa się, że ChRL wolała w tym czasie inwestować w Europie bezpośrednio, miast spełnić nadzieje części polityków europejskich i dokapitalizować Europejski Fundusz Stabilności Finansowej (od października 2012 r. zastąpiony przez Europejski Mechanizm Stabilizacyjny). W ten sposób kierowały do Europy wsparcie kapitałowe przy mniejszym, aniżeli w przypadku zakupu europejskich obligacji, ryzyku i większych możliwościach generowania długofalowych korzyści i pozycji konkurencyjnej rodzimych korporacji. Według danych chińskiego ministerstwa handlu przytaczanych przez dziennik „Beijing Review” w 2011 r. wartość chińskich inwestycji w UE wzrosła aż o 94,1\% (A New Phase, 2012; Merkel po prośbie, 2012). Głównym obszarem zainteresowania chińskich firm sąjak dotąd najbogatsze państwa Unii Europejskiej. Według raportu Rhodium Group, w latach 2000-2011 na rynki piętnastu państw, tworzących UE przed jej rozszerzeniem w 2004 r. trafiło 85\% wszystkich inwestycji z ChRL. Najwięcej pieniędzy (5,7 miliarda USD) zainwestowano we Francji (70 inwestycji, w tym warta 3,24 miliarda USD umowa między China Investment Corporation i GDF Suez). Na drugim miejscu znalazła się Wielka Brytania z inwestycjami wartymi 3,7 miliarda USD (złożyło się nań 95 przedsięwzięć). W Niemczech chińskie przedsiębiorstwa zainwestowały 2,5 miliarda USD, obejmujących 146 inwestycji (Haneman, Rosen, 2012: 36-37). Tabela 1 przedstawia skalę aktywności chińskiego kapitału w poszczególnych państwach Unii Europejskiej w latach 2000-2011.

Analizując dane zawarte w tabeli 1, należy zwrócić uwagę na kilka istotnych czynników. Statystyki określające skumulowaną wartość inwestycji w poszczególnych państwach mogą mylić. W niektórych przypadkach (Francja, Węgry) jedna wielka inwestycja stanowi zdecydowaną większość ulokowanego w tych państwach kapitału. Po drugie, w latach 2000-2011 przedsiębiorstwa chińskie częściej decydowały się na inwestycje typu greenfield, których przeprowadzono 428 wobec 145 akwizycji. Tego typu inwestycje zapewniają łatwiejszy dostęp do rynków UE, pozwalają również na ominięcie części barier handlowych, lepsze dostosowanie produktów do wymogów lokalnego rynku i budowę wizerunku firmy (Gradziuk, Szczudlik-Tatar, 2012: 11). 
Akwizycje i zakup wartościowych aktywów w Europie wymagająjednak zaangażowania znacznie większej ilości kapitału. Mimo mniejszej ilości tego typu transakcji, ich znaczenie z punktu widzenia polityki chińskiej jest bardziej istotne. Ponadto, należy zauważyć, że przedstawione dane obejmują lata 2000-2011, a więc stosunkowo długi okres czasu. Dopiero w ostatnich latach chiński kapitał zaczął wykazywać większe zainteresowanie nabywaniem aktywów europejskich przedsiębiorstw.

Tabela 1

Inwestycje chińskich przedsiębiorstw w państwach Unii Europejskiej w latach 2000-2011 (o wartości równej lub wyższej od 1 miliona USD)

\begin{tabular}{|c|c|c|c|c|}
\hline Państwo & $\begin{array}{c}\text { Wartość } \\
\text { inwestycji } \\
\text { (w milionach USD) }\end{array}$ & $\begin{array}{c}\text { Liczba } \\
\text { projektów typu } \\
\text { greenfield }\end{array}$ & Liczba akwizycji & $\begin{array}{c}\text { Lączna liczba } \\
\text { inwestycji }\end{array}$ \\
\hline Francja & 5722 & 46 & 24 & 70 \\
\hline Wielka Brytania & 3684 & 69 & 26 & 95 \\
\hline Niemcy & 2543 & 113 & 33 & 146 \\
\hline Szwecja & 2251 & 14 & 6 & 20 \\
\hline Węgry & 2085 & 14 & 4 & 18 \\
\hline Holandia & 1164 & 32 & 15 & 47 \\
\hline Belgia & 847 & 12 & 3 & 15 \\
\hline Grecja & 714 & 5 & 0 & 5 \\
\hline Włochy & 554 & 31 & 16 & 47 \\
\hline Austria & 391 & 6 & 5 & 11 \\
\hline Rumunia & 299 & 13 & 1 & 14 \\
\hline Polska & 190 & 15 & 1 & 16 \\
\hline Hiszpania & 187 & 22 & 1 & 23 \\
\hline Czechy & 76 & 10 & 1 & 11 \\
\hline Finlandia & 48 & 1 & 4 & 5 \\
\hline Portugalia & 47 & 5 & 0 & 5 \\
\hline Bułgaria & 47 & 6 & 1 & 7 \\
\hline Luksemburg & 46 & 1 & 1 & 2 \\
\hline Irlandia & 44 & 6 & 1 & 7 \\
\hline Dania & 30 & 6 & 1 & 7 \\
\hline Łotwa & 3,8 & 1 & 0 & 1 \\
\hline Cypr & 3 & 0 & 1 & 1 \\
\hline Estonia & - & - & - & 0 \\
\hline Litwa & - & - & - & 0 \\
\hline Malta & - & - & - & 0 \\
\hline Słowacja & - & - & - & 0 \\
\hline \multirow[t]{2}{*}{ Słowenia } & - & - & - & 0 \\
\hline & 20975,8 & 428 & 145 & 573 \\
\hline
\end{tabular}

Źródło: T. Hanemann, D. Rosen (2012), China Invests in Europe. Patterns, Impacts and Policy Implications, http://rhgroup.net (19.10.2012), s. 38. 
W tabeli 2 ujęto najważniejsze akwizycje i wykup mniejszościowych pakietów akcji przedsiębiorstw z państw UE przez chińskie firmy. Dane obejmują okres od stycznia 2010 do czerwca 2012 r.

Tabela 2

Akwizycje i wykup mniejszościowych pakietów akcji przedsiębiorstw państw Unii Europejskiej ${ }^{3}$ przez chińskie firmy (01.2010-06.2012)

\begin{tabular}{|c|c|c|c|c|c|c|}
\hline Data & Inwestor & $\begin{array}{c}\text { Kwota } \\
\text { (w mln } \\
\text { USD) }\end{array}$ & $\begin{array}{c}\text { Zakupione } \\
\text { udzialy }\end{array}$ & Kontrahent & Sektor & Państwo \\
\hline 2.2010 & CIC & 960 & $2,3 \%$ & Apax Finance & Finansowy & Wielka Brytania \\
\hline 2.2010 & Wanhua Industrial & 190 & & BorsodChem & Chemiczny & Węgry \\
\hline 3.2010 & Geely Auto & 1800 & $\begin{array}{c}\text { zakup mar- } \\
\text { ki Volvo }\end{array}$ & Ford & Samochodowy & Szwecja \\
\hline 1.2011 & CNPC & 510 & $50 \%$ & INEOS & Energetyczny & $\begin{array}{l}\text { Wielka Brytania, } \\
\text { Francja }\end{array}$ \\
\hline 1.2011 & ChemChina & 1990 & $100 \%$ & Orkla & Chemiczny & Norwegia \\
\hline 1.2011 & China Unicom & 500 & $1,4 \%$ & Telefonica & $\begin{array}{l}\text { Telekomunikacyj- } \\
\text { ny }\end{array}$ & Hiszpania \\
\hline 2.2011 & Wanhua Industrial & 1660 & $58 \%$ & BorsodChem & Chemiczny & Węgry \\
\hline 5.2011 & Fosun International & 120 & $10 \%$ & FolliFollie & Inny & Grecja \\
\hline 5.2011 & Zijin Mining & 100 & & Glencore & Metalowy & Szwajcaria \\
\hline 6.2011 & Lenovo & 670 & $100 \%$ & Medion & Informatyczny & Niemcy \\
\hline 8.2011 & CIC & 3240 & $30 \%$ & GDF Suez & Energetyczny & Francja \\
\hline 8.2011 & SAFE & 720 & $3 \%$ & Munich Re & Finansowy & Niemcy \\
\hline 10.2011 & Wolong Holding & 140 & & ATB Group & Samochodowy & Austria \\
\hline 10.2011 & Wanhua Industrial & 260 & & & Chemiczny & Węgry \\
\hline 12.2011 & Three Gorges & 3510 & $21 \%$ & $\begin{array}{l}\text { Energia } \\
\text { de Portugal }\end{array}$ & Energetyczny & Portugalia \\
\hline 1.2012 & Shandong Heavy & 230 & $75 \%$ & Ferretti & Inny & Włochy \\
\hline 1.2012 & Sany Heavy & 480 & $90 \%$ & Putzmeister & Budowlany & Niemcy \\
\hline 1.2012 & $\mathrm{CIC}$ & 920 & $9 \%$ & Thames Water & Rolniczy & Wielka Brytania \\
\hline 2.2012 & State Grid & 510 & $25 \%$ & REN & Energetyczny & Portugalia \\
\hline 5.2012 & COSCO & 150 & & & Żegluga & Grecja \\
\hline 5.2012 & Bright Foods & 1940 & $60 \%$ & Weetabix & Rolniczy & Wielka Brytania \\
\hline 5.2012 & Huawei & 1500 & & & $\begin{array}{l}\text { Telekomunika- } \\
\text { cyjny }\end{array}$ & Węgry \\
\hline 6.2012 & CIC & 490 & $7 \%$ & Eutelsat & $\begin{array}{l}\text { Telekomunikacyj- } \\
\text { ny }\end{array}$ & Francja \\
\hline
\end{tabular}

Źródło: China Global Investment Tracker (2012), The Heritage Foundation, http://www.heritage.org (15.10.2012).

3 Tabela uwzględnia także inwestycje chińskiego kapitału w państwach niebędących członkami Unii Europejskiej, ale należących do EFTA (ang. European Free Trade Agreement) - w tym przypadku Norwegii i Szwajcarii. 
Analiza danych zamieszczonych w tabeli 2 pozwala zauważyć kilka prawidłowości. Po pierwsze, aktywność chińskich przedsiębiorstw zainteresowanych całkowitym bądź częściowym przejmowaniem europejskich firm rośnie. Wartość powyższych transakcji (uwzględniono jedynie te, których wartość przekroczyła 100 milionów USD) w 2010 r. wyniosła 2,96 miliarda USD, w 2011 r. 13,42 miliarda USD, a do końca czerwca 2012 r. było to 6,22 miliarda USD. Po drugie, należy zwrócić uwagę, że wszystkie wymienione przedsiębiorstwa są bądź podmiotami publicznymi, bądź państwo zachowuje duży wpływ na ich działalność i podejmowane decyzje (problem ten zostanie rozwinięty w dalszej części niniejszego artykułu). Po trzecie, zainteresowanie chińskich przedsiębiorstw koncentruje się na dwóch obszarach: sektorze energetycznym, a także sektorach związanych ze sferą wysokich technologii (m.in. sektor telekomunikacyjny, chemiczny, informatyczny). W przypadku inwestycji w sektor energetyczny, możliwość pozyskania nowoczesnych technologii także jest jednym z czynników przyciagających zainteresowanie firm z ChRL.

W zestawieniu z wyżej opisanymi inwestycjami zaangażowanie kapitału z ChRL w Polsce należy uznać za relatywnie małe. Największą dotychczasową inwestycją jest zakup przez chiński koncern Guangxi LiuGong Machinery za blisko 300 milionów złotych cywilnej części Huty Stalowa Wola (Wirtualny Nowy Przemyst, 2012). Zakumulowana wartość bezpośrednich inwestycji zagranicznych w 2010 roku wyniosła 140 milionów USD (Gradziuk, Szczudlik-Tatar, 2012: 11). TCL i Digital View produkują w Polsce (odpowiednio w Żyrardowie i Koszalinie) telewizory i monitory LCD, Nuchtech utworzył pod Warszawą fabrykę skanerów do prześwietlania pociagów i pojazdów, GD Poland w Wólce Kosowskiej zajmuje się dystrybucją towarów. Chińskie inwestycje pojawiły się także w branży IT - w Polsce działają Huawei i ZTE Cop (ibidem: 15).

Pomimo niedużego zainteresowania chińskich firm inwestycjami w Polsce, kilka czynników pozwala sądzić, iż sytuacja ta może w bliższej przyszłości ulec zmianie. Po pierwsze, w ostatnim czasie doszło do wyraźnej intensyfikacji kontaktów politycznych między Polską a ChRL. Analiza dotychczasowej polityki państwa chińskiego wskazuje na silną ,ekonomizację” polityki zagranicznej i powiązanie współpracy na płaszczyźnie politycznej z gospodarczym zaangażowaniem (Szatlach, 2010: 174). Można więc wnioskować, że ChRL postrzega Polskę jako ewentualnego kontrahenta i miejsce lokowania przyszłych inwestycji. Wynika to w dużej mierze z faktu, iż Polska postrzegana jest jako lider grupy państw regionu Europy Środkowo-Wschodniej, który ChRL traktuje jako potencjalny obszar ekspansji inwestycyjnej ${ }^{4}$. Do wzrostu zainteresowania chińskich firm przyczyniło się prawdopodobnie powodzenie, jakim cieszył się polski pawilon w czasie światowej wystawy Expo 2010 w Szanghaju (Szczudlik-Tatar, 2010: 54) ${ }^{5}$.

4 W opublikowanym w 2011 r. raporcie Europejskiej Rady Spraw Zagranicznych, pt. Wyścig po Europe autorzy - Francois Godement i Jonas Parello-Plesner zauważają, że 10\% inwestycji chińskiego kapitału trafia do państw Europy Środkowo-Wschodniej. Liczba ta w zestawieniu z wielkością gospodarek tych państw jest zdaniem autorów nieproporcjonalnie duża, co ma świadczyć o silnym zainteresowaniu ChRL budową wpływów gospodarczych właśnie w tym regionie. Szerzej: F. Godement, J. Parello-Plesner (2011), Wyścig po Europe, Warszawa, s. 12.

${ }^{5}$ Przed i w czasie EXPO 2010 Chińczycy wykonali wobec Polski kilka znaczących gestów: m.in. polski pawilon znalazł się na plakacie i w oficjalnym biuletynie promującym to przedsięwzięcie, bar- 
Wartym odnotowania jest jednak przede wszystkim rozwój dialogu na najwyższych szczeblach władzy państwowej. W grudniu 2011 roku w czasie spotkania w Pekinie prezydenci obu państw - Bronisław Komorowski i Hu Jintao podpisali umowę o partnerstwie strategicznym (Polsko-chińskie partnerstwo, 2012). Z kolei 25 kwietnia 2012 r. w Warszawie odbyło się forum gospodarcze Polska-Europa Środkowa-Chiny, w którym oprócz przedstawicieli piętnastu państw Europy Środkowej (Polski, Bośni i Hercegowiny, Chorwacji, Czarnogóry, Czech, Estonii, Litwy, Łotwy, Macedonii, Rumunii, Serbii, Słowacji, Słowenii, Bułgarii i Węgier), wzięła udział delegacja chińska z premierem Wen Jiabao na czele. Była to pierwsza od 25 lat wizyta premiera ChRL w Polsce (Premier Chin, 2012).

Szczególne zainteresowanie Europą Środkowo-Wschodnią i uznanie Polski za najważniejszego partnera $\mathrm{w}$ regionie to drugi z powodów, nakazujących rozpatrywać chińskie zaangażowanie inwestycyjne w Polsce jako możliwe w bliskiej przyszłości. W czasie wspomnianego forum gospodarczego premier Wen zapowiedział kilka istotnych inicjatyw. Chodzi między innymi o ustanowienie wartej 10 miliardów USD linii kredytowej, w ramach której na preferencyjne kredyty mogłyby liczyć wspólne przedsięwzięcia podmiotów chińskich z partnerami w regionie - przede wszystkim na polu rozwoju infrastruktury, wysokich technologii i ,zielonej” energii. Wen zadeklarował także chęć utworzenia wartego 500 milionów USD funduszu wsparcia inwestycji. Zapowiedział ponadto zwiększenie wartości wzajemnej wymiany handlowej do $100 \mathrm{mi}-$ liardów USD w 2015 r. Kolejne propozycje odnosiły się między innymi do współpracy na płaszczyźnie edukacji (podejmowania studiów w Polsce przez chińskich studentów i naukowców), zachęcania chińskich przedsiębiorstw do współpracy z partnerami z państw Europy Środkowo-Wschodniej, a także kooperacji na polu inwestycyjnym, w sektorze budowlanym, przy budowie infrastruktury i w branży turystycznej. Wszystkie postulaty i rozwiązania odnoszą się do regionu Europy Środkowej jako całości (Polska $w$ wielobiegunowym, 2012).

Po trzecie, swoje oddziały w Warszawie otworzyły chińskie banki - Bank of China oraz Industrial and Commercial Bank of China. Głównym zadaniem obu będzie prawdopodobnie wsparcie chińskich przedsiębiorstw zainteresowanych wejściem na rynek polski, a także na rynki innych państw regionu. Potwierdza to tylko poważne plany Chińczyków względem Europy Środkowej, a ulokowanie oddziałów obu banków właśnie w Polsce to kolejna przesłanka wskazująca na uznanie jej za najpoważniejszego kontrahenta w regionie (Chiński bank, 2012; Chiński ICBC, 2012). Przy uwzględnieniu wyżej wymienionych czynników, można stwierdzić, że Polska i region Europy Środkowej leżą w orbicie zainteresowań chińskich przedsiębiorstw realizujących strategię go global. Zasadnym jest jednak pytanie jak chiński kapitał postrzegany jest w Europie i w Polsce, a także jakie potencjalne szanse i zagrożenia dla państw europejskich stanowi rosnąca obecność i znaczenie chińskich przedsiębiorstw na kontynencie europejskim.

dzo dogodna była również lokalizacja polskiego pawilonu, a ponadto ówczesny marszałek Sejmu - Grzegorz Schetyna, jako jeden z pięciu gości (obok sekretarza generalnego ONZ - Ban Ki-moona, premiera ChRL Wen Jiabao, premiera Węgier Victora Orbana i premier Finlandii Mari Kiviniemi) został poproszony o wygłoszenie przemówienia na zakończenie wystawy. 


\section{OCENA CHIŃSKIEJ EKSPANSJI INWESTYCYJNEJ W PAŃSTWACH EUROPEJSKICH}

Reakcja europejskich decydentów na wzrost aktywności chińskiego kapitału pozostaje trudna do przewidzenia. Jeszcze w 2007 r. kanclerz Niemiec Angela Merkel proponowała utworzenie unijnej agencji na wzór amerykańskiego Komitetu ds. Inwestycji Zagranicznych (CFIUS) ${ }^{6}$. Agencja ta miałaby chronić europejskie przedsiębiorstwa przed tzw. ,,wrogimi przejęciami” przez kapitał państw trzecich. Propozycja jej utworzenia odnosiła się w dużej mierze do ryzyka przejmowania europejskich firm przez podmioty z ChRL i Rosji (Kamiński, 2008: 59-60). Wydaje się jednak, że poważne problemy europejskiej gospodarki oddaliły perspektywę utworzenia tego typu instytucji. Obecnie chińscy inwestorzy postrzegani są przede wszystkim jako źródło bardzo potrzebnego Europie kapitału i inwestycji. Problem ewentualnego politycznego wykorzystania ekspansji na rynki europejskie przez chińskie władze, mające decydujący wpływ na działania rodzimych firm na rynkach zagranicznych, odszedł na dalszy plan, choć w dalszym ciagu toczy się na ten temat dyskusja. Propozycję powołania specjalnej instytucji, mającej prawo wetowania niebezpiecznych dla bezpieczeństwa państw UE inwestycji zagranicznych przedstawili w 2010 r. Komisji Europejskiej komisarz ds. rynku wewnętrznego Michel Barnier i komisarz ds. przemysłu Antonio Tajani. Inicjatywa ta nastąpiła po tym, jak mało znana chińska firma Xinmao usiłowała przejąć holenderski Draka Holding, oferując cenę znacznie wyższą aniżeli europejscy konkurenci (chińska oferta sięgnęła 1,3 miliarda USD, wobec propozycji 1 miliarda USD złożonej przez włoską firmę Prysmian). Jedna z filii holenderskiego holdingu zajmuje się między innymi produkcją kabli przeznaczonych dla armii europejskich i amerykańskiej. Wywołało to podejrzenia o subsydiowanie tej inicjatywy przez państwo chińskie, usiłujące uzyskać dostęp do ważnych z punktu widzenia bezpieczeństwa technologii (W unii, 2012; Choduń, Nowicki, 2012).

Należy podkreślić, że ChRL nie traktuje Unii Europejskiej jako w pełni jednolitego rynku. ChRL dostrzega i stara się wykorzystać występujące między poszczególnymi państwami UE różnice. Najważniejszym partnerem pozostają dla Chin Niemcy - najsilniejsza gospodarka europejska i państwo, z którym ChRL posiada najwyższe obroty handlowe ${ }^{7}$. Tam też trafia (liczbowo) najwięcej inwestycji z „Państwa Środka” (patrz: dane zawarte w tabeli 1). Zróżnicowane są jednak także oceny, sposób postrzegania i preferowana przez poszczególne państwa UE polityka wobec ChRL. Mimo oparcia relacji ekonomicznych z „Państwem Środka” o struktury unijne, państwa europejskie starają się także rozwijać współpracę bilateralną z azjatyckim partnerem, usiłując uzy-

${ }^{6}$ Komitet ds. Inwestycji Zagranicznych (ang. Committee on Foreign Investment in the United States - CFIUS) - międzyagencyjny komitet, którego zadaniem jest ocena transakcji, mogących doprowadzić do zagrożenia bezpieczeństwa narodowego USA poprzez przejęcie przez podmioty obce kontroli nad amerykańskim biznesem. Patrz: U.S. Department of the Treasury, http://www.treasury.gov (23.10.2012).

7 Niemcy są czwartym pod względem wielkości partnerem handlowym ChRL. Roczna wartość wymiany handlowej między tymi państwami wyniosła w 2011 r. 133,45 miliarda USD. Patrz: The World Factbook, 2012. 
skać jak największe korzyści dla siebie (Kamiński, 2008: 63). W raporcie $A$ Power Audit of EU-China Relations z 2009 r. przygotowanym przez Johna Foxa i Francois Godement dla European Council on Foreign Relations wyróżniono cztery grupy państw w ramach Unii Europejskiej na podstawie ich stosunku do rozwijania współpracy z ChRL na płaszczyznach politycznej i ekonomicznej. „Asertywni industrialiści” (Niemcy, Polska, Czechy) opowiadali się za utrzymaniem presji na ChRL zarówno w sferze polityki, jak i gospodarki. „Ideologiczni zwolennicy wolnego handlu” (Dania, Holandia, Szwecja, Wielka Brytania) sprzeciwiali się restrykcjom handlowym zarówno po stronie unijnej, jak i przede wszystkim chińskiej. „Przyjaźni merkantyliści” (Grecja, Bułgaria, Finlandia, Cypr, Węgry, Włochy, Malta, Portugalia, Rumunia, Słowacja, Słowenia, Irlandia, Hiszpania, Francja) przy stosunkowo przyjaznym, względnie neutralnym podejściu politycznym, starali się chronić i zachować kontrolę nad własnym rynkiem (czyli de facto ograniczyć możliwości ekspansji chińskiego kapitału). „Europejscy naśladowcy" (Austria, Belgia, Litwa, Łotwa, Estonia, Luksemburg) odpowiedzialność za relację z Chinami ,przerzucali” na ponadnarodowe instytucje UE, nie angażując się indywidualnie (Brodsgaard, Hong, 2008: 11-12; Fox, Godement, 2009). Wskutek zawirowań, jakie mają miejsce w globalnej gospodarce, wyodrębnione w 2009 r. podziały wydają się być nieaktualne. Dlatego Francois Godement i Jonas Parello-Plesner proponują nowy podział. Ich zdaniem państwa uznane za ,asertywnych industrialistów", jak Polska i Czechy, w coraz większym stopniu zabiegają o chińskie inwestycje. To samo dotyczy dużej części ,przyjaznych merkantylistów” - w szczególności państw takich, jak: Grecja, Włochy, Hiszpania i Portugalia - szukających w chińskiej aktywności i inwestycjach sposobu na złagodzenie skutków kryzysu ekonomicznego. Trudno wskazać też państwa niezainteresowane indywidualnym kształtowaniem relacji z Chinami, znika więc stopniowo grupa „europejskich naśladowców”. F. Godement i J. Parello-Plesner w dzisiejszej Europie wyodrębniają dwie grupy państw: „sfrustrowanych wolnorynkowców” i ,ubogich amatorów kontraktów”. Pierwsza grupa, którą tworzą Wielka Brytania, Niemcy i Francja domaga się wzajemności i szerszego dostępu na rynek chiński dla przedsiębiorstw z Europy. Ich zdaniem możliwość ekspansji chińskich przedsiębiorstw w Europie powinna wiązać się ze stopniową likwidacją barier taryfowych i pozataryfowych, utrudniajacych od wielu lat europejskim firmom operowanie na rynku chińskim. Państwom tym zależy także na koordynacji działań w ramach struktur i instytucji unijnych, ponieważ w ten sposób państwa UE uzyskują silniejszą pozycję negocjacyjną wobec ChRL. Druga grupa państw zainteresowana jest przede wszystkim przyciąnnięciem chińskich inwestycji (zalicza się do niej w chwili obecnej zdecydowana większość członków UE). Zdecydowanie mniejszy nacisk stawia ona na problem, „wzajemności” w swobodnym dostępie do rynku. Tłumaczyć można to z jednej strony doraźną polityką motywowaną problemami gospodarczymi, z drugiej mniejszą aniżeli w przypadku Niemiec, Francji czy Wielkiej Brytanii liczbą dużych przedsiębiorstw zainteresowanych poważną ekspansją na rynek chiński i będących w stanie podjąć na nim walkę konkurencyjną. W efekcie czego problem otwarcia rynku chińskiego jest dla tych państw sprawą drugorzędną (Godement, Parello-Plesner, 2011: 27-32; Starzyk, 2009: 399-404).

Należy uznać, że ChRL stara się wykorzystać brak spójności w stanowisku państw UE do realizacji własnych interesów ekonomicznych. Dąży, zdaniem części obser- 
watorów, do utworzenia swego rodzaju bazy do dalszej ekspansji w Europie. Bazą tą mogą być państwa grupy PIIGS (Portugalia, Irlandia, Włochy, Grecja, Hiszpania), dotknięte w szczególny sposób kryzysem gospodarczym i liczące na aktywność inwestycyjną oraz pomoc finansową z zewnątrz. Mogą stać się nią także państwa Europy Środkowo-Wschodniej. Świadczyć o tym może opisywana już wizyta premiera Wen Jiabao na warszawskim forum gospodarczym Polska-Europa Środkowa-Chiny.

Raport F. Godemonta i J. Parello-Plesnera w sposób krytyczny odnosi się do polityki poszczególnych państw Unii Europejskiej wobec rosnącej aktywności inwestycyjnej przedsiębiorstw z ChRL. Wprowadzony podział należy jednak uznać za bardzo ogólny. Zrównanie relatywnie biernej polityki Polski, z bardzo aktywnie zabiegającymi o chińskie inwestycje Węgrami (Kałan, 2012: 6) czy znajdującą się w skrajnie trudnej sytuacji gospodarczej Grecją może być mylące. Polityka Polski, jak już wspomniano, wydaje się być stosunkowo bierna i w znacznej mierze przypadkowa. Do niedawna bliższa współpraca gospodarcza z ChRL wydawała się pomysłem ,egzotycznym”, a relacje z państwem chińskim postrzegano w sposób emocjonalny i ideologiczny, głównie przez pryzmat polityki i zagadnień takich, jak np. problem Tybetu (Góralczyk, 2009: 399-404). Możliwości i potencjalne korzyści ze zwiększonej kooperacji na płaszczyźnie ekonomicznej znajdowały się na dalszym planie. Obecny stopniowy rozwój współpracy na płaszczyźnie politycznej i potencjalnie gospodarczej jest więc w polskiej polityce zjawiskiem nowym. Wydaje się jednak, że pożądane ramy i zakres tej kooperacji nie zostały przez polskie władze w pełni zdefiniowane. Trudno wskazać jasno określone cele, brakuje także refleksji nad szansami i potencjalnymi zagrożeniami, jakie generuje ewentualne zwiększenie obecności przedsiębiorstw z ChRL na rynkach europejskich, w tym także polskim (Gradziuk, Szczudlik-Tatar, 2012: 18; Polska w wielobiegunowym, 2012: 18-21).

Tabela 3

Podział państw Unii Europejskiej pod względem stosunku do relacji z Chińską Republiką Ludową na płaszczyźnie politycznej i gospodarczej

\begin{tabular}{|c|c|c|}
\hline Grupa & Państwa & Stosunek do relacji z ChRL \\
\hline 1 & 2 & 3 \\
\hline \multicolumn{3}{|c|}{ Podzial przed globalnym kryzysem gospodarczym } \\
\hline \begin{tabular}{|l} 
Asertywni \\
industrialiści
\end{tabular} & Niemcy, Polska, Czechy & $\begin{array}{l}\text { - utrzymanie politycznej i gospodarczej presji } \\
\text { państw europejskich na Chiny }\end{array}$ \\
\hline $\begin{array}{l}\text { Ideologiczni } \\
\text { zwolennicy } \\
\text { wolnego handlu }\end{array}$ & $\begin{array}{l}\text { Dania, Holandia, Wielka Brytania, } \\
\text { Szwecja }\end{array}$ & $\begin{array}{l}\text { - dążenie do uzyskania szerszego dostępu na chiń- } \\
\text { ski rynek, } \\
\text { - sprzeciw wobec restrykcji handlowych }\end{array}$ \\
\hline $\begin{array}{l}\text { Przyjaźni } \\
\text { merkantyliści }\end{array}$ & $\begin{array}{l}\text { Grecja, Bułgaria, Finlandia, Irlandia, } \\
\text { Cypr, Węgry, Włochy, Malta, Portuga- } \\
\text { lia, Rumunia, Słowacja, Słowenia, Hisz- } \\
\text { pania, Francja }\end{array}$ & $\begin{array}{l}\text { - neutralne podejście na płaszczyźnie politycz- } \\
\text { nej, } \\
\text { - chęć zachowania kontroli nad rynkiem, zwolen- } \\
\text { nicy protekcjonizmu gospodarczego }\end{array}$ \\
\hline $\begin{array}{l}\text { Europejscy } \\
\text { naśladowcy }\end{array}$ & $\begin{array}{l}\text { Austria, Belgia, Luksemburg, Litwa, } \\
\text { Lotwa, Estonia }\end{array}$ & $\begin{array}{l}\text { - brak indywidualnego zaangażowania, } \\
\text { - przeniesienie ciężaru relacji z ChRL na ponadna- } \\
\text { rodowe instytucje UE }\end{array}$ \\
\hline
\end{tabular}




\begin{tabular}{|c|c|c|}
\hline 1 & 2 & 3 \\
\hline \multicolumn{3}{|c|}{ Obecny podzial } \\
\hline $\begin{array}{l}\text { Sfrustrowani } \\
\text { wolnorynkowcy }\end{array}$ & Niemcy, Francja, Wielka Brytania & $\begin{array}{l}\text { - żądanie wzajemności w relacjach handlowych } \\
\text { i szerszego dostępu do rynku chińskiego, } \\
\text { - zwolennicy wspólnej, solidarnej polityki handlo- } \\
\text { wej Unii Europejskiej wobec ChRL }\end{array}$ \\
\hline $\begin{array}{l}\text { Ubodzy amato- } \\
\text { rzy kontraktów }\end{array}$ & $\begin{array}{l}\text { W różnym stopniu zdecydowana więk- } \\
\text { szość państwa UE }\end{array}$ & $\begin{array}{l}\text { - chęć przyciągnięcia kapitału i inwestycji z ChRL, } \\
\text { - ,jednostronne” uzależnienie - najczęściej rela- } \\
\text { tywnie nieduże możliwości eksportu i inwesty- } \\
\text { cji na rynku chińskim, } \\
\text { - w znacznej mierze państwa dotknięte przez kry- } \\
\text { zys gospodarczy }\end{array}$ \\
\hline
\end{tabular}

Źródło: Opracowanie własne na podstawie: J. Fox, F. Godement (2009), A Power Audit of EU-China Relations, http://ecfr.eu/ (19.10.2012); oraz F. Godement, J. Parello-Plesner (2011), Wyścig po Europe, Warszawa.

\section{POTENCJALNE ZAGROŻENIA WYNIKAJĄCE Z ZAANGAŻOWANIA INWESTYCYJNEGO CHIŃSKICH FIRM W EUROPIE}

W artykule wskazano aspekty, które decydują o zainteresowaniu państw europejskich przyciąganiem chińskich inwestorów. Z czysto ekonomicznego punktu widzenia jest to bowiem dla Europy szansa na pobudzenie gospodarki, utworzenie nowych, bądź utrzymanie istniejących miejsc pracy, a co za tym idzie łagodzenie skutków perturbacji gospodarczych. Chińskie przedsiębiorstwa rozwijające swoją działalność na rynkach europejskich mogą ponadto przyczynić się do zwiększenia konkurencji (Hanemann, Rosen, 2012: 51-52). Nie jest jednak przypadkiem, że taka optyka zaczęła dominować wśród europejskich decydentów stosunkowo niedawno wraz z załamaniem się koniunktury gospodarczej. Ucichły także pojawiające się wcześniej obawy, związane z zaangażowaniem chińskiego kapitału w Europie. Obawy te ogniskowały się wokół kilku istotnych problemów, z których większość wiąże się z bezpośrednimi lub pośrednimi powiązaniami między aktywnymi w Europie podmiotami z ChRL i interesami Chińskiej Republiki Ludowej.

Po pierwsze, część obserwatorów obawia się politycznych konsekwencji wzrostu znaczenia Chin w Europie. Chodzi w tym przypadku o wykorzystanie znaczenia chińskich przedsiębiorstw w celu wywarcia na państwa europejskie presji w kwestiach politycznych. Wiązałoby się to z ograniczeniem możliwości wywierania przez państwa europejskie nacisku na Chiny w takich kwestiach, jak: ochrona praw człowieka, reforma systemu politycznego czy utrzymywanie zaniżonego kursu juana w obawie przed ekonomicznymi konsekwencjami takich działań. Podając przykłady działań polityków europejskich, starających się ,nie drażnić” ChRL sugeruje się, że tendencja ta może ulec pogłębieniu. Wskazuje się na przykład na zachowanie byłego prezydenta Francji Nicolasa Sarkozy'ego, który obawiając się reakcji chińskich władz wielokrotnie odkładał spotkanie z duchowym przywódcą Tybetańczyków - Dalajlamą, a kiedy już do tego spotkania doszło, starał się bagatelizować jego znaczenie (Sarkozy minimalizuje, 2012). O tym, że konflikt polityczny może mieć bezpośrednie przełożenie na współpracę ekonomiczną przekonała się w ostatnim czasie Japonia. Skutkiem chińsko-japoń- 
skiego sporu o położone na Morzu Wschodniochińskim wyspy Senkaku/Diaoyudao jest między innymi poważny spadek sprzedaży japońskich produktów na rynku chińskim - dotyczy to między innymi japońskich koncernów samochodowych takich jak Nissan, Honda i Toyota (Gorsza roczna prognoza, 2012).

Drugi rodzaj wątpliwości dotyczy bezpośredniego zagrożenia, jakie generuje obecność chińskiego kapitału dla bezpieczeństwa narodowego państw europejskich. Wspomniany już w artykule raport Rhodium Group wymienia najważniejsze z nich. Jednym z podnoszonych zarzutów jest problem skupienia się chińskich przedsiębiorstw na sektorach umożliwiających nabycie technologii. Sprawia to, zdaniem krytyków, że chińskie przedsiębiorstwa na rynkach europejskich kierują się innymi aniżeli rynkowe motywacjami. W skrajnych sytuacjach podmiotom z ChRL zarzuca się działania szpiegowskie - problem ten dotyczy przede wszystkim rynku amerykańskiego, ale budzi także obawy wielu środowisk w Europie. Zwraca się również uwagę na ryzyko związane z ewentualnym umożliwieniem chińskim firmom przejmowania strategicznej z punktu widzenia interesu państwa infrastruktury (np. portów czy infrastruktury energetycznej). Wiele dyskusji wywołuje zainteresowanie przedsiębiorstw z ChRL europejskim sektorem telekomunikacyjnym (Hanemann, Rosen, 2012: 60-61). Najdalej w kwestii przeciwdziałania zaangażowaniu inwestycyjnemu chińskich firm, w niektórych sektorach gospodarki posunęły się Stany Zjednoczone ${ }^{8}$. Komisja ds. Wywiadu przy Kongresie w przygotowanym raporcie stwierdziła, że Huawei Technologies i ZTE Corp (które działają także na rynkach europejskich, w tym w Polsce) stanowią zagrożenie dla bezpieczeństwa narodowego USA. Firmy te mogą bowiem, zgodnie z wolą rządu w Pekinie ingerować w amerykański sektor telekomunikacyjny. W raporcie zwrócono między innymi uwagę na brak chęci pełnej kooperacji ze strony przedstawicieli

8 Stany Zjednoczone skłonne są blokować duże chińskie inwestycje tam, gdzie stanowi to, ich zdaniem, zagrożenie dla bezpieczeństwa państwa. W 2005 r. w przetargu na zakup kalifornijskiej firmy paliwowej Unocal najkorzystniejszą ofertę przedstawiło chińskie China National Offshore Oil Corporation (CNOOC) proponując 18,5 miliarda USD - o 1 miliard więcej aniżeli najpoważniejszy konkurent. Nie zdecydowano się jednak sprzedać Unocal, argumentując to obawami dotyczącymi przejęcia przez chińską firmę kontrolowaną przez państwo technologii, objęcia przez nią kontroli nad ważnymi aktywami w Zatoce Meksykańskiej i na Alasce, a także przypuszczeniami o znacznym wsparciu CNOOC przez rząd chiński. W 2007 r. odrzucona została także propozycja Huawei, które w spółce z amerykańskim Bain Capital chciało przejąć 3Com Corporation - producenta między innymi podzespołów do tworzenia sieci komputerowych. Oferta 2,2 miliarda USD została jednak wycofana po tym jak Komitet ds. Inwestycji Zagranicznych zaopiniował propozycję fuzji, jako generującą zagrożenie dla bezpieczeństwa państwa. Z podobnych powodów wycofana została także oferta China Northwest Nonferrous International Investment Company, chcącej nabyć w 2009 r. 51\% udziałów w spółce wydobywczej Firstgold Corporation. CFIUS uznała, że część kopalni należących do CNNIIC znajduje się zbyt blisko amerykańskich instalacji wojskowych. Względy bezpieczeństwa narodowego przesądziły także o niepowodzeniu innych wielkich transakcji. W $2010 \mathrm{r}$. TCIC za 27,8 miliona USD chciało przejąć od Emcore Corporation 60\% udziałów w dziale zajmującym się produkcją światłowodów. W tym samym roku przedstawiciele Huawei wyrazili chęć kupna amerykańskiego przedsiębiorstwa 3 Leaf Systems. Obie transakcje zostały zablokowane, dodatkowo USA zaprotestowały przeciwko udziałowi Huawei w przetargach, sugerując że działania tej firmy mogą mieć charakter szpiegowski. Patrz: W. Morrison (2012), China - U.S. Trade Issues, http://www.fas.org/ (3.11.2012), s. 18; oraz A. Popis-Benesz (2008), Stosunki USA-Chiny w pierwszej dekadzie XXI wieku, w: „Powrót smoka”. Marsz ku pozycji globalnego mocarstwa, (red.) J. Marszałek-Kawa, Toruń, s. 125 . 
Huawei $\mathrm{w}$ toku postępowania, w tym między innymi: brak kompletnych i przejrzystych informacji na temat struktury korporacyjnej i procesu podejmowania decyzji, brak jasności co do bardzo prawdopodobnych powiązań firmy z rządem chińskim, brak wyjaśnień co do znaczenia funkcjonowania komisji Komunistycznej Partii Chin w ramach przedsiębiorstwa (formalnie będącego akcjonariatem pracowniczym), braku jasnych wyjaśnień co do powiązań Huawei z chińską armią czy podejrzenie o łamanie przez koncern praw własności intelektualnej (Komisja Izby Reprezentantów ds. Wywiadu, 2012). Aktywność Huawei na rynku europejskim i rzekome powiązania tej firmy z Chińską Armią Ludowo-Wyzwoleńczą wywołują także dyskusję w Europie, gdzie jej działalność nie spotyka się $\mathrm{z}$ takimi ograniczeniami. Firma uczestniczy $\mathrm{w}$ blisko połowie zapowiadanych projektów superszybkiej sieci $4 \mathrm{G}$, jest także bardzo silna w branży telefonii komórkowej'.

Po trzecie, zauważa się, że selektywne zaangażowanie ChRL w Europie i skupienie się na bezpośredniej współpracy z państwami członkowskimi, z pominięciem instytucji i struktur Unii Europejskiej może w przyszłości sprawić, że w Europie powstanie swoiste chińskie lobby zdolne przeciwstawić się niekorzystnej z punkty widzenia interesów ChRL polityce. Prowadzenie przez każde z państw własnej, często zróżnicowanej polityki wobec Chin osłabia także ich potencjał negocjacyjny. To z kolei oddala w czasie możliwość rozwiązania problemów z dostępem do rynku chińskiego, jakie napotykają firmy europejskie (przede wszystkim w obszarze zamówień publicznych). Mając możliwość swobodnego dostępu do rynków europejskich, Chińczycy nie będą zainteresowani rezygnacją ze stosowanego protekcjonizmu gospodarczego (Godement, Parello-Plesner, 2011: 12-14).

Po czwarte, zwraca się uwagę na ryzyko prowadzenia przez przedsiębiorstwa chińskie nieuczciwej konkurencji, co związane jest z trudnymi do udowodnienia możliwościami finansowania ich przez państwo. Państwo chińskie stara się kreować tzw. „krajowych czempionów”. Chodzi o duże międzynarodowe koncerny o rozpoznawalnej marce zdolne do skutecznej konkurencji na rynkach globalnych (Gradziuk, Szczudlik-Tatar, 2012: 9). W ramach tej polityki władze ChRL wspierają działania dużych państwowych korporacji, działających na rynkach zagranicznych między innymi poprzez nisko oprocentowane pożyczki i kredyty eksportowe udzielane przez państwowe banki. Chińskie firmy mogą liczyć także na zwolnienia podatkowe, a część z nich korzysta z państwowych subsydiów. Sprawia to, że uzyskują one przewagę konkurencyjna, której, niemogące liczyć na publiczną pomoc, przedsiębiorstwa europejskie nie są w stanie sprostać. W ten sposób negatywne konsekwencje gospodarcze w postaci celowego osłabienia, bądź wyeliminowania miejscowej konkurencji mogą przewyższyć ekonomiczne korzyści. Państwowa pomoc faworyzuje ponadto chińskie przedsiębiorstwa biorące udział w przetargach na wykonanie projektów infrastrukturalnych (The state, 2012).

Formułowane są postulaty ewentualnych działań, które miałyby zneutralizować pojawiające się zagrożenia. F. Godement i J. Parello-Plesner w swojej pracy podkreślają

9 Pojawiają się wprawdzie sugestie, że Huawei może wykorzystywać budowane sieci do podsłuchu w czasie pokoju, ponadto mogą zostać one wyłączone na wypadek wojny. W ten sposób mogłyby stać się narzędziem cyberwalki. Patrz: „The Economist”, 2012. 
konieczność przeciwdziałania tendencjom do prowadzenia przez państwa UE współpracy z ChRL z pominięciem struktur i instytucji unijnych. Ich zdaniem umożliwia to Chinom uzyskanie szerokiego dostępu do rynku europejskiego, bez konieczności szerszego otwarcia rynku chińskiego dla inwestorów z państw UE. Swoje propozycje formułują na trzech płaszczyznach. Po pierwsze, proponują stworzenie bądź systemu statystycznego, zawierającego informacje o zagranicznych pakietach długu publicznego bądź skoordynowanego systemu, który zapewni, że państwa UE będą stosowały podobne metody księgowania. To rozwiązanie miałoby się przyczynić do większej przejrzystości w przypadku wykupu obligacji państw UE przez ChRL. Drugim z proponowanych rozwiązań jest rozszerzenie uprawnień departamentów rynku wewnętrznego i handlu na nadzór inwestycji. Instytucja nadzorująca powinna sprawdzać inwestycje w szczególnie istotnych dziedzinach pod kątem europejskiego bezpieczeństwa i swobody. Podkreślono przy tym, że powołanie tego typu instytucji powinno być elementem multilateralnej polityki państw UE. Trzecia z propozycji dotyczy konkurencji w zamówieniach publicznych. Zdaniem autorów rozwiązaniem mogłaby być na przykład odmowa dotowania przez UE projektów, w których uczestniczą państwa, odmawiające dostępu do swoich rynków. Inną możliwością byłoby stworzenie indeksu ilościowego zagranicznych udziałów w rynkach publicznych. W obu przypadkach celem wprowadzonych zmian miałoby być uzyskanie dostępu do chińskiego rynku zamówień publicznych na zasadzie wzajemności (Godement, Parello-Plesner, 2011: 33-36). Część z wyżej opisanych postulatów doczekała się częściowej realizacji. Na poziomie Unii Europejskiej udało się wprowadzić możliwość zamykania europejskiego rynku zamówień publicznych, dla firm z państw, które same stosują protekcjonizm na tej płaszczyźnie (W unii, 2012).

T. Hanemann i D. Rosen w swoich propozycjach również odwołują się do pomysłu stworzenia jednolitego mechanizmu kontroli kapitału inwestycyjnego na poziomie europejskim. Takie rozwiązanie, ograniczające rolę państwa wobec zagadnień związanych z bezpieczeństwem, byłoby jednak z politycznego punktu widzenia trudne do wprowadzenia. Dlatego autorzy, jako ewentualną alternatywę proponują stworzenie wspólnych ram prawnych, które stanowiłyby punkt wyjścia dla analiz systemów bezpieczeństwa prowadzonych przez poszczególne państwa i przyjmowanych przez nie rozwiązań. Państwa UE powinny przy tym pamiętać o konieczności skutecznego kontrolowania inwestycji zagranicznych z ChRL pod kątem ich wpływu na bezpieczeństwo państwa (Hanemann, Rosen, 2012: 69-73).

***

Rosnące zaangażowanie inwestycyjne kapitału z ChRL w Europie - przede wszystkim w państwach członkowskich Unii Europejskiej wiąże się zarówno z szansami, jak i pewnymi zagrożeniami dla państw europejskich. W ich interesie leży wprowadzenie rozwiązań prawnych pozwalających na wykorzystanie napływu kapitału inwestycyjnego z Azji bez tworzenia zagrożenia dla bezpieczeństwa państwa.

Zaprezentowane przykłady zdecydowanych działań Stanów Zjednoczonych (upatrujących częstokroć w ekspansji chińskiego kapitału poważnego zagrożenia dla bezpieczeństwa narodowego), składające się na swoistą politykę USA, wynikają w pewnej 
mierze z charakteru dwustronnych relacji z ChRL. Państwo to jest traktowane przez USA jako najpoważniejszy rywal na arenie międzynarodowej, z którym bezpośrednio rywalizują o wpływy - przede wszystkim na kontynencie azjatyckim. Wpływa to w naturalny sposób na wzajemne postrzeganie się obu państw. Relacje ChRL z państwami UE w znacznie większej mierze zdeterminowane są przez czynniki czysto ekonomiczne, aspekt polityczny znajduje się natomiast na drugim planie (Kamiński, 2008: 66). Stąd też obawy o negatywne konsekwencje chińskiej ekspansji inwestycyjnej dla bezpieczeństwa narodowego państw, jakkolwiek są przedmiotem dyskusji, nie budzą aż takich emocji.

Polska, jak dotychczas, cieszy się bardzo ograniczonym zainteresowaniem przedsiębiorstw z ChRL. Niemniej rozwój kontaktów politycznych i wyraźne zainteresowanie Chin regionem Europy Środkowo-Wschodniej nakazuje zakładać, że państwo to może być w przyszłości zainteresowane zwiększeniem obecności gospodarczej w tej części Europy. Implikuje to konieczność dyskusji nad szansami i zagrożeniami, jakie z tego wynikają.

Chińskie zaangażowanie inwestycyjne w Europie to nie tylko skutek osłabienia państw europejskich. To także efekt globalizacji polityki ekonomicznej ChRL, która stała się już de facto mocarstwem globalnym i również w skali globalnej postrzega swoje interesy gospodarcze. Zainteresowanie kapitału inwestycyjnego z ChRL rynkiem europejskim, w tym potencjalnie także Polską, nie jest więc prawdopodobnie zjawiskiem sezonowym, wynikającym ze sprzyjających okoliczności. Z tego powodu istotne jest jasne określenie celów polskiej polityki wobec ChRL, a także zaangażowanie w ustanowienie ram skoordynowanej polityki Unii Europejskiej, tam gdzie jej stworzenie i implementacja może przyczynić się do ochrony interesów ekonomicznych państw członkowskich (np. w kwestii otworzenia dostępu do przetargów publicznych w ChRL dla przedsiębiorstw z Europy).

Ekspansja kapitału inwestycyjnego z ChRL, poza szansami i korzyściami gospodarczymi, niesie za sobą także potencjalne zagrożenia. Polska, wykazując zainteresowanie przyciagnięciem chińskich bezpośrednich inwestycji zagranicznych, powinna wdrożyć odpowiednie mechanizmy umożliwiające neutralizację owych zagrożeń. Pewne ograniczenia w prowadzeniu działalności w Polsce wprowadza Ustawa o swobodzie działalności gospodarczej z 2004 r., wskazując obszary, w których prowadzenie działalności gospodarczej wymaga uzyskania państwowej koncesji. Jest to (zgodnie $\mathrm{z}$ art. 46) działalność w zakresie:

1) poszukiwania, rozpoznawania złóż węglowodorów oraz kopalin stałych objętych własnością górniczą, wydobywania kopalin ze złóż, podziemnego bezzbiornikowego magazynowania substancji oraz podziemnego składowania odpadów;

2) wytwarzania i obrotu materiałami wybuchowymi, bronią i amunicją oraz wyrobami i technologią o przeznaczeniu wojskowym lub policyjnym;

3) wytwarzania, przetwarzania, magazynowania, przesyłania, dystrybucji i obrotu paliwami i energia;

4) ochrony osób i mienia;

5) rozpowszechniania programów radiowych i telewizyjnych, z wyłączeniem programów rozpowszechnianych wyłącznie w systemie teleinformatycznym, które nie są rozprowadzane naziemnie, satelitarnie lub w sieciach kablowych; 
6) przewozów lotniczych;

7) prowadzenia kasyna gry.

Decyzja o udzieleniu, odmowie udzielenia, zmianie i cofnięciu koncesji lub ograniczenia jej zakresu należy każdorazowo do ministra właściwego ze względu na przedmiot działalności gospodarczej wymagającej uzyskania koncesji (Ustawa, 2004: art. 47). Według ustawy odmowa udzielenia koncesji lub ograniczenie jej może nastąpić między innymi ,ze względu na zagrożenie obronności lub bezpieczeństwa państwa lub obywateli" (Ustawa, 2004: art. 56.1, punkt 2). Organ koncesyjny jest także zobowiązany do kontroli działalności gospodarczej między innymi „,w zakresie obronności lub bezpieczeństwa państwa, ochrony bezpieczeństwa lub dóbr osobistych obywateli (Ustawa, 2004: art. 57.1, punkt 3). W ustawie uregulowano również możliwość tworzenia przez zagraniczne przedsiębiorstwa oddziałów i przedstawicielstw. Art. 91 upoważnia ministra gospodarki do wydania decyzji o zakazie wykonywania działalności gospodarczej przez przedsiębiorcę zagranicznego w ramach oddziału m.in., gdy „...działalność przedsiębiorcy zagranicznego zagraża bezpieczeństwu lub obronności państwa, bezpieczeństwu informacji niejawnych o klauzuli tajności «poufne» lub wyższej lub innemu ważnemu interesowi publicznemu" (Ustawa, 2004: art. 91.1, punkt 3). $\mathrm{W}$ przypadku przedstawicielstw przedsiębiorstw zagranicznych, te same przesłanki upoważniają ministra gospodarki do (Ustawa, 2004: art. 99.1, 99.2, 101.1):

1) odmowy, w drodze decyzji, wpisu do rejestru przedstawicielstw. Odmowa wpisu nie wymaga przy tym uzasadnienia faktycznego;

2) wydania decyzji o zakazie wykonywania działalności przez przedsiębiorcę zagranicznego w ramach przedstawicielstwa.

Ustawa o swobodzie działalności gospodarczej nadaje więc państwu pewne uprawnienia $\mathrm{w}$ zakresie kontroli przedsiębiorstw zagranicznych prowadzących działalność gospodarczą w Polsce pod kątem ich ewentualnego negatywnego wpływu na stan bezpieczeństwa narodowego. Uprawnienia te obejmują częśc strategicznych z punktu widzenia interesów państwa sektorów gospodarki. Niemniej dobrym pomysłem wydaje się powołanie ponadresortowej instytucji zajmującej się opiniowaniem dużych inwestycji zagranicznych w Polsce pod względem ich wpływu na stan bezpieczeństwa narodowego, przy założeniu, że ustanowienie takiej instytucji na szczeblu Unii Europejskiej ze względów politycznych będzie w najbliższym czasie trudne do zrealizowania. Instytucja taka mogłaby kontrolować duże inwestycje (przede wszystkim fuzje i przejęcia) w obszarach innych aniżeli wymienione w ustawie. Jej działania charakteryzowałyby się więc przede wszystkim znacznie większą elastycznością.

Chińskiego kapitału inwestycyjnego nie należy rozpatrywać jedynie jako potencjalnego zagrożenia. Ewentualne zaangażowanie się przedsiębiorstw z ChRL na rynku polskim stanowi przede wszystkim szansę na uzyskanie korzyści gospodarczych, zwiększenie konkurencji czy nowe miejsca pracy. Stąd należy zgodzić się z postulatami i propozycjami rozwiązań, mających na celu zwiększenie atrakcyjności polskiego rynku dla inwestycji z ChRL (Gradziuk, Szczudlik-Tatar, 2012: 20). W tym kontekście należy także podkreślić, że w wielu państwach zagrożenia przypisywane ekspansji chińskiego kapitału wynikają po części z obaw lokalnych przedsiębiorców, obawiających się trudnej konkurencji. Istotnym jest, by retoryka przeciwdziałania zagrożeniom bezpieczeństwa państwa nie stała się instrumentem protekcjonizmu gospodarczego (Who's afraid, 
2012). Występujących zagrożeń nie można przy tym lekceważyć. Kwestią kluczową pozostaje więc stworzenie prawnych możliwości odpowiedniej kontroli i nadzoru chińskich inwestycji w Polsce, a także sformułowanie długofalowej polityki i strategii w stosunkach Polski z ChRL, także od strony relacji ekonomicznych.

\section{Bibliografia}

A New Phase for Sino-EU Economic Ties, „Beijing Review”, http://www.bjreview.com/ (15.10.2012).

Brodsgaard K., Hong W. (2008), EU-China Relations. Implications and Policy Responses for the United States, http://csis.org/ (19.10.2012).

China Global Investment Tracker (2012), The Heritage Foundation, http://www.heritage.org (15.10.2012).

Chiński bank rozpoczyna ekspansję od Polski, http://www.bankier.pl (22.10.2012).

Chiński ICBC, największy bank na świecie, ma już swoje biuro w Warszawie, http://forsal.pl (22.10.2012).

Choduń M., Nowicki M., Chińczycy wyruszyli na podbój świata. Czy wykupiq Unię Europejskq?, „Newsweek”, http://www.newsweek.pl (2.11.2012).

EBC będzie skupowat obligacje (2012), http://www.bankier.pl (2.11.2012).

Fox J., Godement F. (2009), A Power Audit of EU-China Relations, http://ecfr.eu/ (19.10.2012).

Godement F., Parello-Plesner J. (2011), Wyścig po Europe, Warszawa.

Gorsza roczna prognoza Nissana (2012), http://www.ekonomia24.pl (30.10.2012).

Góralczyk B. (2009), Polska-Chiny: co dalej?, w: Polska-Chiny. Wczoraj, dziś, jutro, (red.) B. Góralczyk, Toruń.

Gradziuk A., Szczudlik-Tatar J. (2012), Perspektywy rozwoju wspótpracy gospodarczej Polski z Chińska Republikq Ludowa, Warszawa.

Hanemann T., Rosen D. (2012), China Invests in Europe. Patterns, Impacts and Policy Implications, http://rhgroup.net (19.10.2011).

Kałan D. (2012), Relacje o specjalnym znaczeniu? Chiny w polityce zagranicznej Wegier w okresie rzadów Victora Orbana (2010-2012), „Biuletyn Europy Środkowo-Wschodniej - Puls Regionu", nr 1.

Kamiński T. (2008), Problemy gospodarcze w relacjach Unii Europejskiej z Chinami, w: „Powrót smoka”. Marsz ku pozycji globalnego mocarstwa, (red.) J. Marszałek-Kawa, Torun.

Merkel po prośbie w Pekinie, „Rzeczpospolita”, http://www.rp.pl/ (15.10.2012).

Morrison W. (2012), China-U.S. Trade Issues, http://www.fas.org/ (3.11.2012).

Polska w wielobiegunowym świecie. Szanse i perspektywy rozwoju stosunków Polski z głównymi mocarstwami wschodzacymi (2012), Raport PISM, (red.) A. Gradziuk, P. Kugiel, Warszawa.

Polsko-chińskie partnerstwo strategiczne (2012), „Rzeczpospolita”, http://www.rp.pl (21.10.2012).

Popis-Benesz A. (2008), Stosunki USA-Chiny w pierwszej dekadzie XXI wieku, w: , Powrót smoka”. Marsz ku pozycji globalnego mocarstwa, (red.) J. Marszałek-Kawa, Toruń.

Premier Chin pierwszy raz w Polsce od 25 lat. Przyciagniemy chińskie inwestycje? (2012), http://wyborcza.biz/ (25.10.2012).

Sarkozy minimalizuje znaczenie spotkania z Dalajlama (2012), „Rzeczpospolita”, http://www.rp.pl (3.11.2012). 
Starzyk K. (2009), Stosunki gospodarcze Polski z Chinami na tle ich przemian w latach 1978-2008, w: Polska-Chiny. Wczoraj, dziś, jutro, (red.) B. Góralczyk, Torun.

Streaks of red. Capital and companies from China are sidling into Europe (2012), „The Economist”, http://www.economist.com (2.11.2012).

Szatlach M. (2010), Strategia gospodarcza wspótczesnych Chin-wybrane aspekty polityki wewnętrznej i międzynarodowej, w: Historia. Polityka. Stosunki międzynarodowe. Wybrane zagadnienia, (red.) A. Zaćmiński, Bydgoszcz.

Szczudlik-Tatar J. (2010), Powrót do gry. Od oblężonej twierdzy do odpowiedzialnego partnera - ewolucja polityki zagranicznej ChRL (1949-2010), „Polski Przegląd Dyplomatyczny”, rocznik $60, \mathrm{nr} 2$.

The state advances (2012), „The Economist”, 6.10.2012.

Ustawa z dnia 2 lipca 2004 roku o swobodzie działalności gospodarczej, Dz. U. 2004, Nr 173, poz. 1807 z późn. zm.

Who's afraid of Huawei? (2012), „The Economist”, 4.08.2012.

W unii z Unia czy z Pekinem? Czy Chińczycy świadomie podminowuja UE? (2012), http://wyborcza.biz (2.11.2012).

\title{
STRESZCZENIE
}

Celem artykułu jest analiza szans i zagrożeń, które generuje chińskie zaangażowanie inwestycyjne w państwach Unii Europejskiej, a także możliwości przeciwdziałania jego ewentualnym negatywnym konsekwencjom. Ostatnie lata przyniosły ze sobą wyraźny wzrost zainteresowania przedsiębiorstw z Chińskiej Republiki Ludowej podejmowaniem działalności inwestycyjnej w państwach Unii Europejskiej. Można przy tym zakładać utrzymanie się tej tendencji w najbliższym czasie. Poza korzyściami ekonomicznymi, które generuje chińskie zaangażowanie inwestycyjne, wskazuje się także na pewne zagrożenia z tym związane. Problem ten powinien stać się także obiektem zainteresowania polskich decydentów. Mimo relatywnie niewielkiej dotychczas aktywności chińskich przedsiębiorstw w Polsce, Chiny wydają się być zainteresowane zwiększeniem obecności gospodarczej w Europie Środkowo-Wschodniej, Polskę traktując jako lidera państw regionu.

\section{EXPANSION OF CHINESE INVESTMENT IN EUROPE - POTENTIAL CHANCES AND THREATS FOR POLAND}

\begin{abstract}
The aim of this article is to analyse the opportunities and threats generated by the Chinese investment activity in the EU (including Poland), and also possibilities to counter its potential negative consequences. In recent years, the interest of Chinese companies to invest in the European market has grown significantly. In all likelihood this tendency can be a constant trend in the near future. Apart from economic benefits generated by the Chinese investment, there are also some possible threats and risks related to this activity. Polish policy-makers should also be more aware of these issues. Although the present activity of Chinese enterprises in Poland has been relatively small, China seems to be interested to increase its economic presence in Central and Eastern Europe, and Poland is considered as a leading country in the region.
\end{abstract}

